\title{
Kesiapan Guru Kelas Melaksanakan Layanan Bimbingan dan Konseling di Sekolah Dasar Se-Kota Padang
}

\author{
Suci Mustika Putri, Khairani, Yusri \\ Universitas Negeri Padang, Padang \\ Email: sucimustikaputri96@gmail.com
}

\begin{abstract}
Readiness is someone condition that makes it ready to give a response in makes the point particular to the situation. This research intent for (1) describe teacher readiness braze to perform guidance and counselling service at elementary school one City of Padang is seen of science aspect, (2) describe teacher readiness braze to perform guidance and counselling service at elementary school the one City of Padang is seen of skill aspect, (3) describe teacher readiness braze to perform guidance and counselling service at elementary school the one City of Padang is seen of attitude aspect. This observational type is observational descriptive quantitative. Indigenous observational population teacher brazes elementary school (SD) one City of total Padang 429 teachers braze 4, 5 and 6. The sample were taken to utilize Technic Cluster Random Sampling, so gotten by sample amount as much 37 teachers braze 4, 5, and 6. Research performed by administers instrument questionnaires. Data analysed by percentage analysis. The research findings reveal the teacher readiness braze to perform guidance and counselling service at elementary school one City of Padang in the good category.
\end{abstract}

Keywords: Teacher Readiness Braze, Guidance and Counselling, Elementary School

(1) Licensees may copy, distribute, display and perform the work and make derivative works and remixes based on it only if they give the author or licensor the credits (attribution) in the manner specified by these. Licensees may copy, distribute, display, and perform the work and make derivative works and remixes based on it only for non-commercial purposes.

\section{PENDAHULUAN}

Pendidikan harus dipahami sebagai bagian dari proses pembudayaan subjek didik sehingga bukan hanya pengalihan penguasaan ilmu perngetahuan serta pelatihan serta penguasaan keterampilan-keterampilan teknis tertentu, namun juga perlu dipahami sebagai penumbuhan dan pengembangan subjek didik menjadi pribadi manusia yang berbudaya dan beradab (Saat, 2015).

Mulai dari Pendidikan Anak Usia Dini (PAUD) hingga Perguruan Tinggi (PT), sekolah dasar merupakan lembaga pendidikan dengan masa pendidikan yang cukup lama yaitu enam tahun, oleh karena itu guru kelas sangat berperan penting dalam mengoptimalkan tugas perkembangan murid.

Dalam menjalankan tugas perkembangannya peserta didik sering menemui hambatan-hambatan dan permasalahan-permasalahan sehingga mereka banyak bergantung kepada orang lain, oleh karena itu anak usia SD memerlukan perhatian khusus dari para guru (Nurihsan, 2003).

Kegiatan pembelajaran di SD yang diselenggarakan berupa kegiatan pendidikan dan pengajaran untuk mengembangkan kemampuan peserta didik, salah satunya yaitu layanan bimbingan dan konseling yang 
dilaksanakan oleh guru kelas, seperti yang tertera pada Permendikbud No 81A tahun 2013 tentang implementasi kurikulum: pedoman umum pembelajaran, substansi bimbingan dan konseling di SD/MI/SDLB menyatakan guru kelas sebagai pelaksana pelayanan BK di SD/MI/SDLB melaksanakan layanan orientasi, informasi, penempatan dan penyaluran, dan penguasaan konten dengan cara menginfusikan materi layanan bimbingan dan konseling tersebut ke dalam pembelajaran mata pelajaran.

Bimbingan dan konseling merupakan suatu kajian komprehensif tentang prosedur atau langkah-langkah dalam memberikan bantuan terhadap individu (klien) dalam rangka pengembangan diri dan pengentasan masalah klien yang mencakup segenap aspek kehidupannya (Hariko, 2016). Bimbingan adalah proses pemberian bantuan yang dilakukan oleh seorang ahli kepada individu dengan menggunakan berbagai prosedur, cara dan bahan agar individu tersebut mampu mandiri dalam memecahkan masalah yang dihadapinya, sedangkan konseling merupakan proses proses pemberian bantuan yang didasarkan pada prosedur wawancara konseling oleh seorang ahli yang bermuara pada teratasinya masalah yang dihadapi klien (Kartiko, Hartati, \& Saraswati, 2014).

Bimbingan dan konseling sebagai salah satu bagian penting dalam pendidikan karakter memiliki posisi yang signifikan untuk menangani permasalahan tersebut. Pelayanan bimbingan dan konseling dianggap cukup efektif untuk membantu siswa dalam mengembangkan aspek-aspek kognitif, afektif dan psikomotor pada siswa sekolah dasar (Ardimen, 2017).

Untuk terlaksananya layanan BK di SD, sangat diperlukan kesiapan guru kelas untuk melaksanakan layanan BK tersebut, karena selain menjadi seorang guru kelas dengan tuntutan mengajar siswa asuhnya dengan berbagai mata pelajaran, seorang guru kelas juga memiliki tugas lainnya yaitu memberikan layanan BK.

Tugas seorang guru di samping sebagai pengajar adalah sebagai pendidik. Sebagai pengajar, guru mengajarkan ilmu pengetahuan, sedangkan sebagai pendidik guru menstimulasi siswa untuk mengembangkan sikap dan perilaku mereka agar sesuai dengan kaidah perilaku warga negara yang diharapkan masyarakat dan negara. Selain itu guru juga sebagai pelaksana layanan bimbingan konseling di sekolah dasar yang mempunyai peran penting dalam membangun sikap disiplin siswa di sekolah (Hayati, 2016).

Terlaksananya layanan BK di SD, sangat diperlukan kesiapan guru kelas untuk melaksanakan layanan BK tersebut, karena selain menjadi seorang guru kelas dengan tuntutan mengajar siswa asuhnya dengan berbagai mata pelajaran, seorang guru kelas juga memiliki tugas lainnya yaitu memberikan layanan BK.

Kesiapan adalah keseluruhan kondisi seseorang yang membuatnya siap untuk memberi respon/jawaban di dalam cara tertentu terhadap suatu kondisi (Slameto, 2013). Kesiapan seseorang merupakan sifatsifat dan kekuatan pribadi yang berkembang, perkembangan ini memungkinkan orang itu untuk dapat menyesuaikan diri dengan lingkungannya serta mampu memecahkan masalah persoalan yang selalu dihadapinya (Dalyono, 2007).

Kesiapan guru kelas melaksanakan layanan BK dapat dilihat dari kompetensi yang dimilikinya, kompetensi seorang guru. yaitu pengetahuan (kognitif), sikap (afektif) dan keterampilan (psikomotor) (Sudijono, 2016). Berdasarkan pembahasan tersebut, peneliti tertarik untuk meneliti tentang kesiapan guru kelas melaksanakan layanan bimbingan dan konseling di sekolah dasar se-Kota Padang.

Fenomena yang peneliti temukan dari hasil wawancara dan observasi yang dilakukan pada saat melaksanakan magang untuk memenuhi tugas mata kuliah diagnostik kesulitan belajar, yaitu masih kurangnya sarana dan prasarana sekolah untuk mendukung pelaksanaan layanan bimbingan dan konseling, tidak adanya program layanan bimbingan dan konseling dalam kurikulum di sekolah dasar, guru kelas belum proaktif tetapi masih menunggu dalam arti baru bereaksi setelah masalah muncul, masih kurangnya minat dan motivasi guru kelas melaksanakan layanan bimbingan dan konseling serta pihak sekolah kurang mendukung pelaksanaan layanan BK mengenai perlengkapan dan dana. Berdasarkan fenomena tersebut peneliti tetarik 
untuk meneliti tentang kesiapan guru kelas melaksanakan layanan bimbingan dan konseling di sekolah dasar se-Kota Padang.

Penelitian ini bertujuan untuk mendeskripsikan kesiapan guru kelas melaksanakan layanan bimbingan dan konseling di sekolah dasar se-Kota Padang dilihat dari aspek pengetahuan, mendeskripsikan kesiapan guru kelas melaksanakan layanan bimbingan dan konseling di sekolah dasar se-Kota Padang dilihat dari aspek keterampilan, mendeskripsikan kesiapan guru kelas melaksanakan layanan bimbingan dan konseling di sekolah dasar se-Kota Padang dilihat dari aspek sikap.

\section{METODE}

Jenis penelitian ini adalah penelitian deskriptif dengan pendekatan kuantitatif.
Sampel dalam penelitian ini dipilih menggunakan teknik random sampling, dengan metode cluster random sampling. Populasi penelitian berasal dari guru kelas 4, 5, dan 6 SD terakreditasi A se-Kota Padang. Sampel diambil menggunakan teknik cluster ramdom sampling, sehingga didapatkan jumlah sampel sebanyak 37 orang guru kelas. Penelitian dilaksanakan dengan mengadministrasikan instrumen angket. Data dianalisis dengan analisis persentase. Instrumen yang digunakan adalah angket model skala Likert dengan lima alternatif jawaban.

\section{HASILPENELITIAN DAN PEMBAHASAN}

Berdasarkan pengolahan data yang telah dilakukan, maka hasil penelitian ini dapat digambarkan sebagai berikut:

Tabel 1.

Rekapitulasi Hasil Penelitian Kesiapan Guru Kelas Melaksanakan Layanan Bimbingan dan Konseling di Sekolah Dasar Se-Kota Padang.

\begin{tabular}{llccccc}
\hline No & $\begin{array}{c}\text { Aspek Kesiapan Guru Kelas } \\
\text { Melaksanakan Layanan Bimbingan dan } \\
\text { Konseling }\end{array}$ & SB & B & CB & TB & STB \\
\cline { 3 - 6 } & & & & & \\
\hline 1. & Aspek Pengetahuan & 29,7 & 54,1 & 16,2 & 0 & 0 \\
2. & Aspek Keterampilan & 37,8 & 62,2 & 0 & 0 & 0 \\
3. & Aspek Sikap & 18,9 & 75,7 & 5,4 & 0 & 0 \\
\hline Keseluruhan & 24,3 & 75,7 & 0 & 0 & 0 \\
\hline
\end{tabular}

Dari rekapitulasi data pada Tabel 1 dapat dilihat bahwa kesiapan guru kelas melaksanakan layanan bimbingan dan konseling di sekolah dasar yang dibagi menjadi tiga sub variabel yaitu kesiapan guru kelas melaksanakan layanan bimbingan dan konseling di sekolah dasar dilihat dari aspek pengetahuan, kesiapan guru kelas melaksanakan layanan bimbingan dan konseling di sekolah dasar dilihat dari aspek keterampilan dan kesiapan guru kelas melaksanakan layanan bimbingan dan konseling di sekolah dasar dilihat dari aspek sikap tergolong pada kategori baik. Dari persentase capaian secara keseluruhan kesiapan guru kelas melaksanakan layanan bimbingan dan konseling di sekolah dasar menunjukkan 24, 3\% guru berada pada kategori sangat baik, 75, 7\% guru berada pada kategori baik, $0 \%$ guru berada pada kategori cukup baik, 0\% guru berada pada kategori tidak baik, dan $0 \%$ guru berada pada kategori sangat tidak baik. Ini artinya kesiapan guru kelas melaksanakan layanan bimbingan dan konseling di sekolah dasar secara keseluruhan dapat dikatakan sudah baik.

Berikut ini akan dijelaskan secara rinci tentang kesiapan guru kelas melaksanakan layanan bimbingan dan konseling di sekolah dasar se-Kota Padang dilihat dari aspek pengetahuan, keterampilan dan sikap.

Berdasarkan hasil analisis deskriptif kesiapan guru kelas melaksanakan layanan bimbingan dan konseling di sekolah dasar dilihat dari aspek pengetahuan 29,7 \% guru berada pada kategori sangat baik, 54,1 guru berada pada kategori baik, 16,2\% guru berada pada kategori cukup baik, serta tidak ada yang berada pada kategori tidak baik dan sangat tidak baik. Ini artinya guru kelas sudah 
memiliki kesiapan pengetahuan yang baik untuk melaksanakan layanan bimbingan dan konseling di sekolah dasar sehingga guru kelas dapat menggunakannya dalam pelaksanaan layanan bimbingan dan konseling di sekolah dasar serta mempertahankan dan meningkatkan kesiapan pengetahuan yang dimiliki oleh guru kelas tersebut agar menjadi lebih baik lagi.

Pengetahuan seringkali disebut juga aspek ingatan (recall), dalam jenjang kemampuan ini seseorang dituntut untuk dapat mengenali atau mengetahui tentang konsep, fakta atau istilah-istilah, dan lain sebagainya dan dapat digunakan (Daryanto, 2012). Sebagai seorang guru kelas harus memiliki pengetahuan yang baik mengenai bimbingan dan konseling sehingga guru kelas dapat menggunakannya untuk melaksanakan layanan bimbingan dan konseling.

Layanan bimbingan dan konseling di sekolah dasar meliputi layanan orientasi, informasi, penempatan/penyaluran, pembelajaran, konseling perorangan, bimbingan kelompok dan konseling kelompok. Seorang guru kelas harus mengetahui dan memahami layanan-layanan BK yang dapat diterapkan di sekolah dasar (Batubara \& Ariani, 2018).

Dalam pembahasan ini kesiapan guru kelas melaksanakan layanan bimbingan dan konseling di sekolah dasar dilihat dari aspek pengetahuan ditinjau dari segi konsep BK dan kegiatan \& layanan yang dapat dilakukan berada pada kategori baik

Berdasarkan hasil analisis deskriptif kesiapan guru kelas melaksanakan layanan bimbingan dan konseling di sekolah dasar dilihat dari aspek keterampilan 37,8\% guru berada pada kategori sangat baik, 67,2\% guru berada pada kategori baik, serta tidak ada guru yang berada pada kategori cukup baik, tidak baik dan sangat tidak baik. Dari hasil analisis tersebut dapat disimpulkan guru kelas sudah memiliki kesiapan keterampilan yang baik untuk melaksanakan layanan bimbingan dan konseling di sekolah dasar sehingga guru kelas dapat menerapkannya dalam pelaksanaan layanan bimbingan dan konseling di sekolah dasar serta mempertahankan dan meningkatkan kesiapan guru kelas melaksanakan layanan BK di SD berdasarkan aspek keterampilan agar menjadi lebih baik lagi.
Keterampilan atau psikomotor adalah ranah yang berkaitan dengan keterampilan (skill) atau kemampuan bertindak setelah seseorang menerima pengalaman belajar tertentu (Sudijono, 2016). Sebagai seorang guru kelas harus memiliki keterampilan atau kemampuan yang baik agar memiliki kesiapan yang baik dalam melaksanakan layanan bimbingan dan konseling.

Dalam pembahasan ini kesiapan guru kelas melaksanakan layanan bimbingan dan konseling di sekolah dasar dilihat dari aspek keterampilan ditinjau dari segi mengenali pribadi murid, melayani murid, dan komunikasi berada pada kategori baik. Kondisi ini mengungkapkan kesiapan guru kelas melaksanakan layanan BK di SD dilihat dari aspek keterampilan perlu dipertahankan dan ditingkatkan.

Berdasarkan hasil analisis deskriptif kesiapan guru kelas melaksanakan layanan bimbingan dan konseling di sekolah dasar dilihat dari aspek sikap 18,9\% guru berada pada kategori sangat baik, $75,7 \%$ guru berada pada kategori baik, 5,4\% guru berada pada kategori cukup, serta tidak ada yang berada pada kategori tidak baik dan sangat tidak baik.Ini artinya guru kelas sudah memiliki kesiapan sikap yang baik untuk melaksanakan layanan bimbingan dan konseling di sekolah dasar sehingga guru kelas dapat menerapkannya dalam pelaksanaan layanan bimbingan dan konseling di sekolah dasar serta mempertahankan dan meningkatkan kesiapan guru kelas melaksanakan layanan BK di SD berdasarkan aspek sikap agar menjadi lebih baik lagi.

Dalam pembahasan ini kesiapan guru kelas melaksanakan layanan bimbingan dan konseling di sekolah dasar dilihat dari aspek sikap ditinjau dari segi tanggungjawab, disiplin, dan kerja sama berada pada kategori baik. Kondisi ini mengungkapkan kesiapan guru kelas melaksanakan BK di SD dilihat dari aspek sikap perlu dipertahankan dan ditingkatkan lagi, agar pelaksanaan layanan BK di SD dapat dilaksanakan dengan maksimal. 


\section{SIMPULAN DAN SARAN}

Berdasarkan hasil penelitian dapat disimpulkan bahwa secara umum, kesiapan guru kelas melaksanakan layanan bimbingan dan konseling di sekolah dasar se-Kota Padang berada pada kategori baik. Kesiapan guru kelas tersebut dilihat dari tiga aspek, yaitu aspek pengetahuan, keterampilan dan sikap. Dari hasil penelitian yang menyatakan bahwa kesiapan guru kelas melaksanakan layanan bimbingan dan konseling di sekolah dasar seKota Padang berada pada kategori baik, ini artinya guru kelas telah dapat melaksanakan layanan BK di sekolah dasar.

Bagi Kepala sekolah, agar dapat mendukung, memberikan fasilitas dan memberikan motivasi untuk kegiatan pelaksanaan layanan bimbingan dan konseling bagi guru kelas di sekolah dasar se-Kota Padang. Jika kepala sekolah memberikan fasilitas dan motivasi kepada guru kelas yang sudah memiliki kesiapan yang baik untuk melaksanakan layanan bimbingan dan konseling, maka guru kelas akan dapat menampilkan kinerja yang baik dalam pelaksanaan layanan bimbingan dan konseling di sekolah dasar. Serta saran bagi agar guru kelas dapat mempelajari konsep-konsep layanan BK di SD dengan membaca bukubuku tentang BK di SD untuk menambah pengetahuan tentang bimbingan dan konseling di SD agar kesiapan guru kelas melaksanakan layanan bimbingan dan konseling di SD dalam aspek pengetahuan dapat ditingkatkan lagi, dan guru kelas dapat menerapkan apa yang telah dipelajarinya tentang bimbingan dan konseling di SD serta mengaplikasikannya di kelas yang menjadi tanggungjawabnya sehingga guru kelas lebih terampil lagi dan kesiapan guru kelas untuk melaksanakan layanan bimbingan dan konseling di SD dalam aspek keterampilan akan lebih meningkat lagi, serta guru kelas tetap menjaga sikapnya sebagai seorang guru kelas dan sebagai contoh teladan yang baik agar menjadi panutan yang baik bagi muridmuridnya di sekolah. Bagi dosen jurusan bimbingan dan konseling FIP UNP dan pihak yang berwenang, dapat membantu dalam memberikan pelatihan mengenai kesiapan dan pelaksanaan layanan bimbingan dan konseling di sekolah dasar kepada guru kelas sekolah dasar di Kota Padang.

Open Access Journal; http://pedagogi.ppj.unp.ac.id/

\section{DAFTAR PUSTAKA}

Ardimen. (2017). Bimbingan dan Konseling Komprehensif Berbasis Karakter Cerdas Dan Aplikasinya Melalui Bimbingan Teman Sebaya Di Era Globalisasi. Jurnal Penelitian Pendidikan Islam, 12(2), 483508. Retrieved from http://journal.stainkudus.ac.id/index.php/ Edukasia/article/view/1681/pdf

Batubara, H. H., \& Ariani, D. N. (2018). Penyelenggaraan Bimbingan dan Konseling di Sekolah Dasar. Jurnal Pendidikan, 3(4), 447-452. Retrieved from

http://journal.um.ac.id/index.php/jptpp/art icle/view/10744/5236

Dalyono. (2007). Psikologi Pendidikan. Jakarta: Rineka Cipta.

Daryanto. (2012). Evaluasi Pendidikan. Jakarta: Rineka Cipta.

Hariko, R. (2016). Ilmu Bimbingan dan Konseling, Nilai dan Kesejahteraan Individu: Studi Literatur. Jurnal Konseling Dan Pendidikan, 4(2), 118123. Retrieved from http://jurnal.konselingindonesia.com/inde x.php/jkp/article/view/160/130

Hayati, F. (2016). Peran Guru Bimbingan dan Konseling Dalam Mengatasi Kecendrungan Perilaku Agresif Peserta Didik di MA. Manajer Pendidikan, 10(6), 503-607. Retrieved from https://ejournal.unib.ac.id/index.php/mana jerpendidikan/article/viewFile/1317/1112

Kartiko, O. D. C., Hartati, M. T. S., \& Saraswati, S. (2014). Persepsi Siswa Terhadap Kinerja Konselor di SMA Negeri Se-Kota Semarang Tahun Pelajaran 2013/2014. Indonesian Journal of Guidance and Counseling: Theory and Application, 3(4), 31-38. Retrieved from https://journal.unnes.ac.id/sju/index.php/.. ./article/.../424...\%0A

Nurihsan, J. (2003). Dasar-Dasar Bimbingan dan Konseling. Bandung: Mutiara.

Saat, S. (2015). Faktor-faktor Determinan dalam Pendidikan. Jurnal Al-Ta'dib, 8(2), 1-17. Retrieved from 
ejournal.iainkendari.ac.id/altadib/article/view/407/392\%0A\%0A

Slameto. (2013). Belajar dan Faktor-faktor yang Mempengaruhi. Jakarta: Rineka

\section{Cipta.}

Sudijono, A. (2016). Pengantar Evaluasi Pendidikan. Jakarta: Rajawali Pers. 